\title{
SOLAR ACTIVITY AND CLIMATE OF THE EARTH
}

\author{
Kirov B. ${ }^{1}$, Georgieva K. ${ }^{1}$, Asenovski S. ${ }^{1}$, Nagovitsyn Yu.A. ${ }^{2}$ \\ ${ }^{1}$ Space Research ant Technologies Institute - BAS, Sofia, Bulgaria \\ ${ }^{2}$ Pulkovo Observatory, Saint Petersburg, Russia
}

\section{СОЛНЕЧНАЯ АКТИВНОСТЬ И КЛИМАТ ЗЕМЛИ}

\author{
Киров Б. ${ }^{1}$, Георгиева К. ${ }^{1}$, Асеновски С. ${ }^{1}$, Наговицын Ю.А. ${ }^{2}$ \\ ${ }^{1}$ Институт Космических исследований и технологий - БАН, София, Болгария \\ ${ }^{2}$ ГАО РАН, Санкт Петербург, Россия
}

\begin{abstract}
Изменения погоды и климата связаны с изменениями атмосферной ичиркуляции. Атмосферная цииркулящия со своей сторонь связана со скоростью вращения Земли или, другими словами, с продолюсительностью суток. Из закона сохранения углового момента следует, что должна быть связь между зональной цииркуляцией и скоростью вращения Земли: усиление зональной ичиркуляичии ведет к замедлению вращения Земли и наоборот. Одним из основных факторов, ведущих к изменениям в глобальной атмосферной циикулящии, являются температурные аномалии. Другой фактор - такое локальное явление, имеющее глобальные последствия, как El Nino/Southern Oscillation (ENSO).

В этой работе мы показываем воздействие солнечной активности на эти явления и, соответственно, на климат Земли.
\end{abstract}

\section{DOI: 10.31725/0552-5829-2019-213-218}

\section{Introduction}

One of the main factors determining the climate changing and weather is the atmospheric circulation. The system of the large-scale atmospheric motions over the Earth (horizontal length scales $>1000 \mathrm{~km}$, persist for a season and longer) Due to:

\section{- differential heating of the Earth's surface}

Because of its sphericity, the Earth gets more energy per unit area in the tropics than at higher latitudes. Това води до heat transport from low to high latitudes. Heated air at the equator rises, proceeds south and north toward the poles, descend there and returns to the equator. If the Earth didn't rotate there would be 2 cells of circulation (one in each hemisphere).

- Earth's rotation

As a result of coriolis forces, 3 cells are formed in each hemisphere (fig. 1). Coriolis acceleration

$$
\boldsymbol{a}_{\mathrm{c}}=-2 \boldsymbol{\Omega} \times \mathbf{v} \sin \varphi
$$

depends on the Earth's rotation rate $\Omega$.

The general atmospheric circulation and rotation of the Earth are closely related due to conservation of the angular momentum of the Earth system $\mathrm{M}$ if the Earth system is closed. 


$$
\begin{aligned}
& \mathrm{d} \mathbf{M} / \mathrm{dt}=0 \\
& \mathbf{M}=\mathrm{M}_{\text {earth }}+\mathrm{M}_{\text {atm }}+\mathrm{M}_{\text {ocean }}+\mathrm{M}_{\text {ice }} \\
& \mathrm{M}_{\mathrm{atm}} \gg>\mathrm{M}_{\text {ocean }}+\mathrm{M}_{\text {ice }}
\end{aligned}
$$

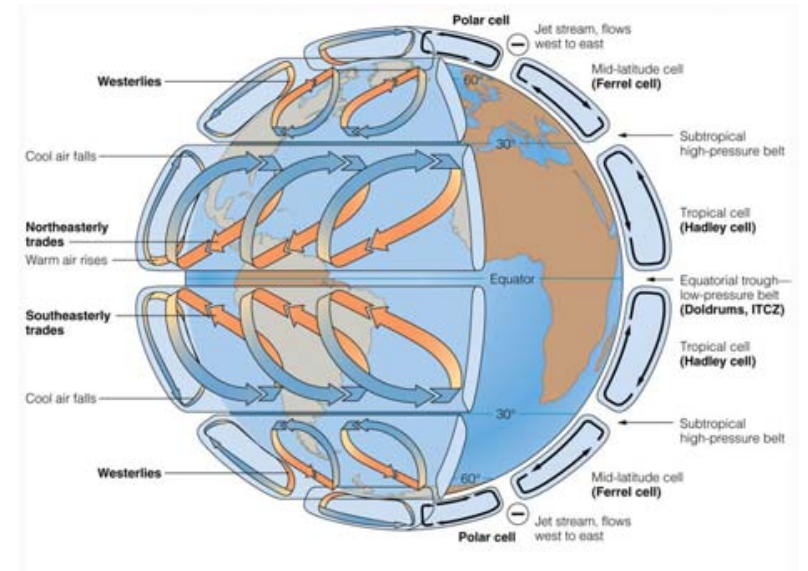

Fig. 1. Atmospheric cells.
The angular momenta of the solid earth and of the atmosphere are the main "players" in the angular momentum balance of the whole system.

Because of conservation of angular momentum: when the westerly winds strengthen, the Earth's rotation rate must decrease, and vice versa Seasonal nontidal

variations in the Earth's rotation rate, or the length of the day (LOD), are explained by the action of the atmospheric "interhemispheric heat machine", fed by the temperature differences between the summer and the winter hemispheres (Sidorenkov) [1]. In July and in January, when the temperature difference between the two hemispheres is greatest, the Earth rotates fastest.

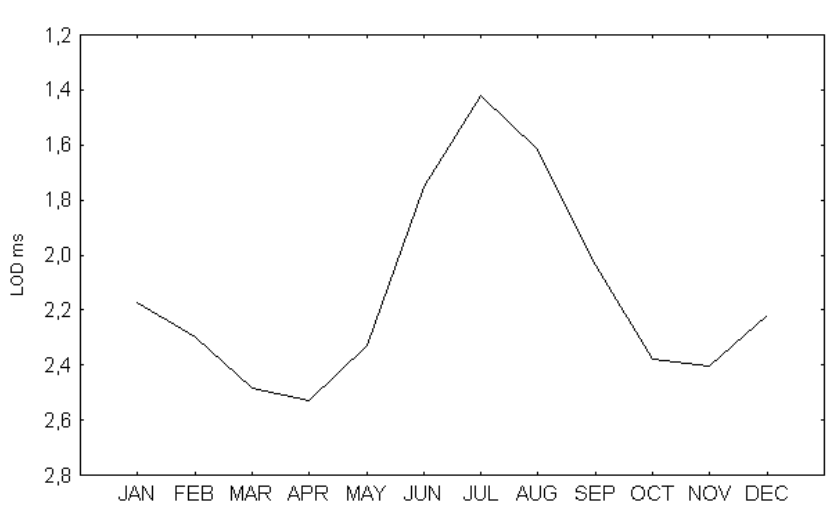

Fig. 2. Annual variations of LOD in $\mathrm{ms}$.

The temperature difference in July is bigger than in January because the Northern hemisphere is on average warmer than the Southern one, so the Earth rotates faster in June than in January. In April and in November, when the temperature in the two hemispheres is almost equal, the rotation rate is minimum

\section{Solar activity and variations in the Earth's rotation rate}

In fig. 2 the seasonal cycle of the Earth rotation is presented for negative polarity solar cycles (NPSC) and positive polarity solar cycles PPSC defined as years of solar activity minimum $+/-2$ years [2]. The curves are derived by the super-posed epochs method from monthly averaged values of daily LOD in the period 1962-2000. The Earth rotation is systematically faster with a negative than with a positive polarity of the Sun. 


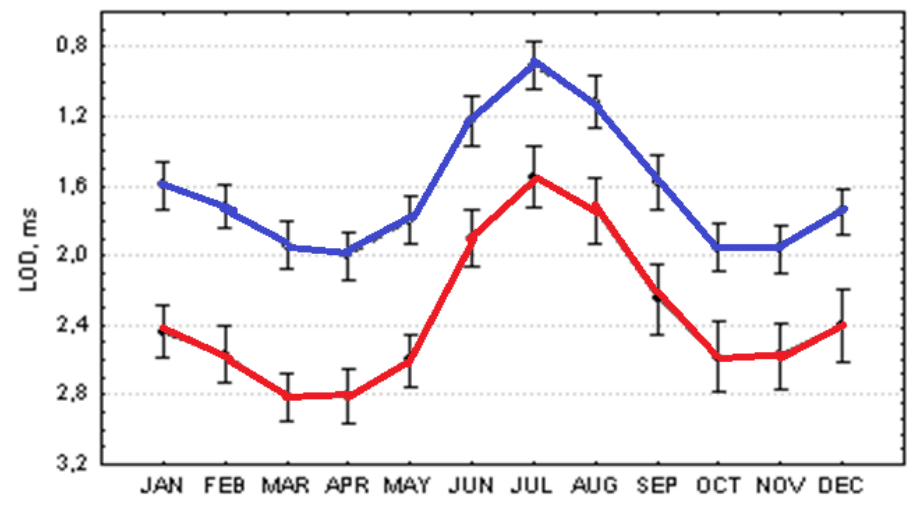

Fig. 3. The same as fig. 1 for PPSC (red line) and NPSC (blue line), together with the error bars.

\section{Atmospheric circulation and climate}

Long-term fluctuations of weather and climate are often related to largescale changes in atmospheric circulation, affecting different and apparently unrelated parts of the hemisphere and even of the whole globe. Examples of such large-scale phenomena are El Niño/ Southern Oscillation and the North Atlantic Oscillation. The North Atlantic Oscillation (NAO) is a north-south seesaw oscillation in atmospheric mass with centers of action near Iceland and over the subtropical Atlantic. NAO exerts a dominant influence on wintertime temperatures across much of the Northern hemisphere. During winter months, NAO variability explains about one-third of the Northern hemisphere interannual surface temperature variance [3].

\section{Atmospheric circulation and Europe}

Solar activity and the resulting geomagnetic activity modulate the largescale atmospheric circulation. Below we compare the frequency and duration of circulation forms according to the Catalog of large-scale atmospheric forms in

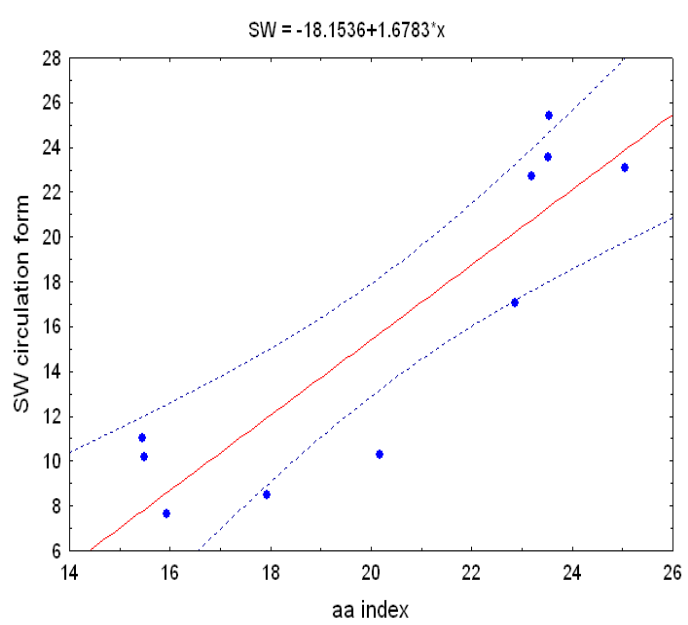

Fig. 4.

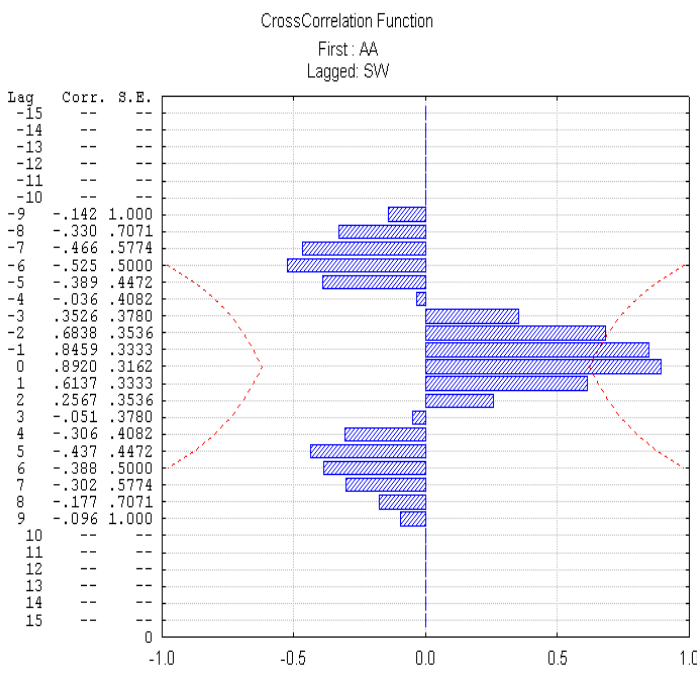

Fig. 5. 
Europe [4] with the aa-index of geomagnetic activity. A very good and highly statistically significant correlation is found between the forms leading to warming in Europe (SW - South-Westerly circulation) and geomagnetic activity (Figs. 4 and 5). On the other hand, with increasing aa-index the frequency and duration of circulation forms leading to cooling (NW - North Westerly) decrease (Figs. 6 and 7),which means that increasing solar, respectively geomagnetic activity leads to warming.

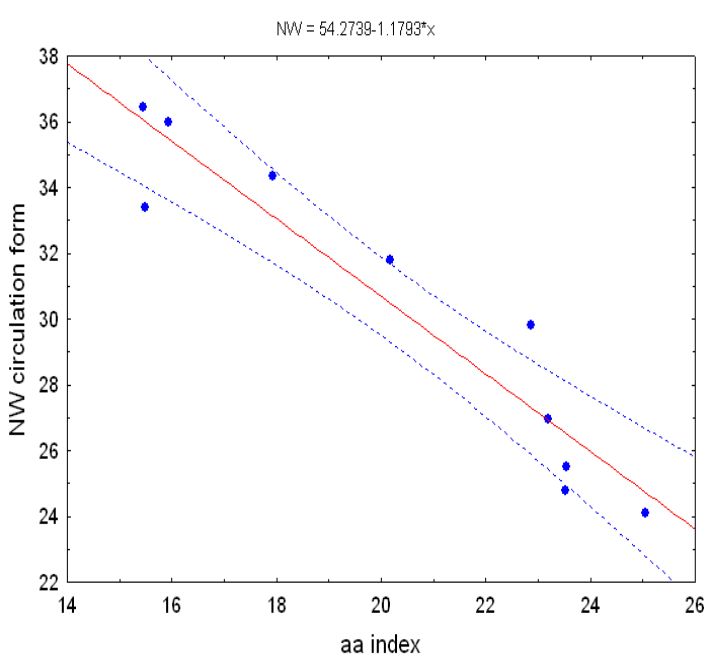

Fig. 6.

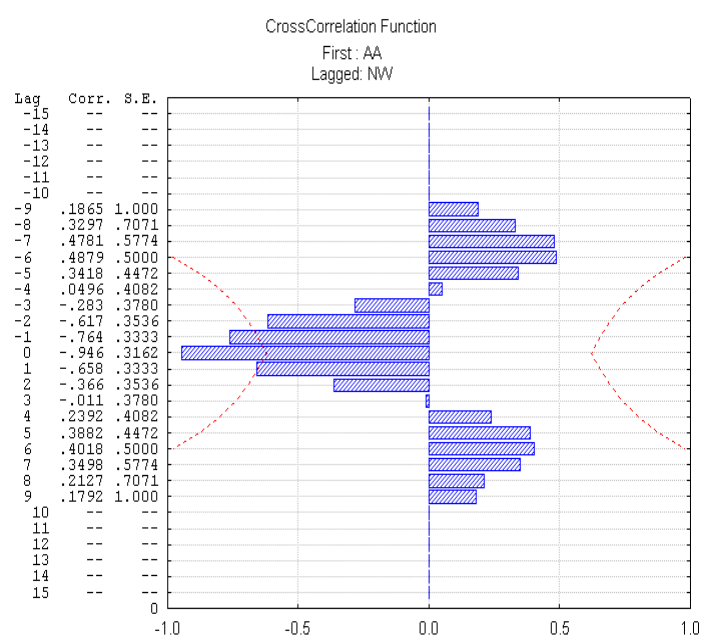

Fig. 7.

\section{ENSO (EI Niño-Southern Oscillation)}

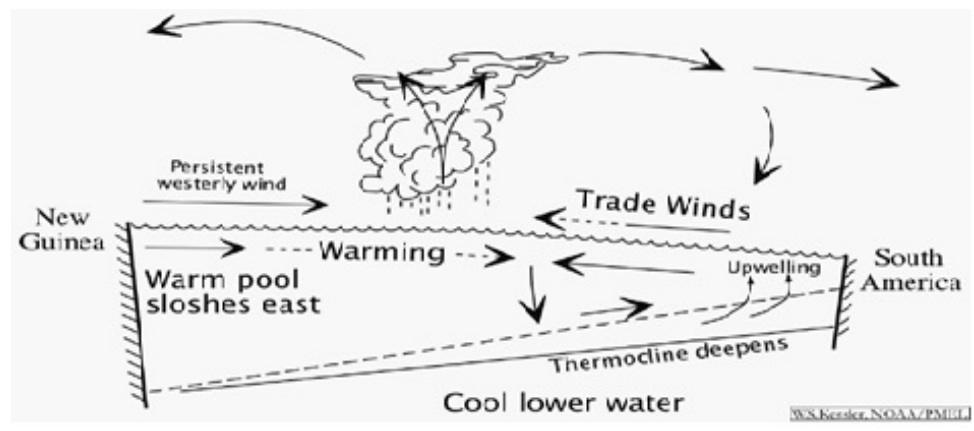

During El Niño events, sea surface temperatures in the east equatorial Pacific Ocean becomes warmer and the center of the west Pacific warm pool migrates eastwards, the trade winds relax in the central and western Pacific leading to a depression of the thermocline in the eastern Pacific, and an elevation of the thermocline in the west. Rainfall follows the warm water eastward, with associated flooding in Peru and drought in Indonesia and Australia. The eastward displacement of the atmospheric heat source overlaying the warmest water results in large changes in the global atmospheric circulation, which in turn force changes in weather in regions far removed from the tropical Pacific [5]. But the fundamental mechanisms behind the variability of El Niño, especially on decadal and longer time-scales, are still unclear. 
The most popular explanation is that the cause of El Niño is Rossby waves. But there is one fact that is underestimated, namely, that El Niño typically occurs in December around Christmas, the period with the greatest temperature difference between the northern and southern hemispheres.

\section{DATA}

To investigate the causes of El Niño, we use the following data:

1. Indices NINO $1+2$ (there are several indices used to monitor the tropical Pacific, all of which are based on Sea Surface Temperature (SST) anomalies averaged across a given region. The Niño $1+2$ region $(0-10 \mathrm{~S}, 90 \mathrm{~W}-80 \mathrm{~W})$ is the smallest and eastern-most of the Niño SST regions, and corresponds with the region of coastal South America where El Niño was first recognized by the local populations, https://climatedataguide. ucar.edu/climate-data/nino-sst-indicesnino-12-3-34-4-oni-and-tni)

2. The deviation from the average monthly velocity of the zonal and meridional winds in the region of $12 \mathrm{~N}$ to $2 \mathrm{~N}$ and from $160 \mathrm{E}$ to $80 \mathrm{~W}$ compared to the average monthly value in the period 1950-1979. The anomaly in the meridian wind has a negative sign when the wind increases from North to South. With a negative sign of the zonal wind anomaly, the wind from east to west weakens.

3 . The deviation from the average monthly temperature value (temperature anomaly) in the following areas +/- 5 degrees; 25 to $35: 55$ to 65 and above 70 degrees in the Northern and Southern Hemispheres, the longitudinal range is from $80 \mathrm{~W}$ to $120 \mathrm{E}$.

\section{A possible cause of EI Niño}

In 1972, there was a major El Niño event.

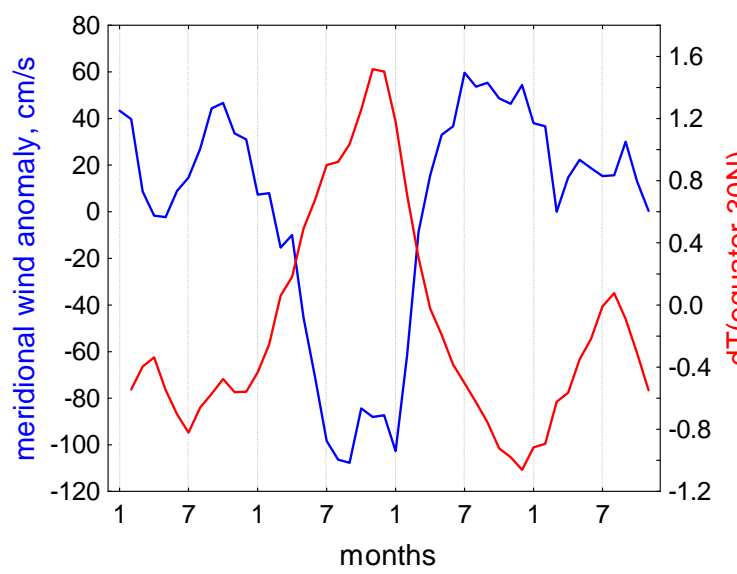

Fig. 8.

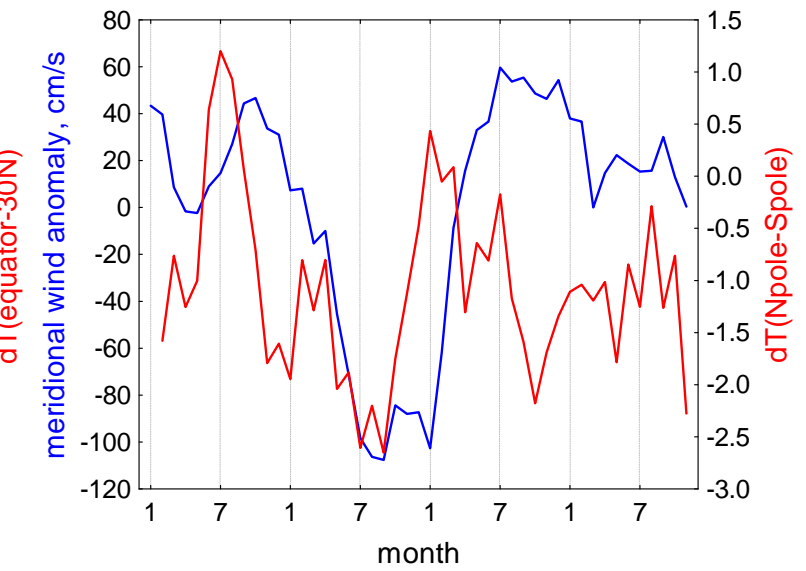

Fig. 9.

We look at the 1971-1974 interval. As can be seen from fig. 9 at the end of 1971, the temperature difference between the equator and the subtropics began to increase, as did the meridional wind. The variation in the meridional wind is 
preceded by an increase in the temperature difference between the north and south Polar Regions (fig. 10).

\section{Summary}

- The general atmospheric circulation is related to the uneven heating of the Earth's surface by solar radiation.

- On the other hand, atmospheric circulation is related to the Earth's rotational rate.

- Solar magnetic field affects the Earth's rotational rate.

- The increase in solar activity leads to an increase in atmospheric circulation in Europe, which leads to warming.

- A major factor of El Nino is the anomaly in the temperature difference between the equator and the tropics.

\section{Refererences}

1. Sidorenkov N.S. Nonuniformities in the Earth's rotation and processes in the atmosphere // Trudy Gidrometcentra SSSR, 1978, Vol. 205, 48-66. (In Russian)

2. Mursula, K., and B. Zieger. Long-term north-south asymmetry in solar wind speed inferred from geomagnetic activity: A new type of century-scale solar oscillation? // Geophys. Res. Lett., 2001, Vol. 28, 95-98.

3. Hurrell, J.W., M.P. Hoerling, and C.K. Folland. Climatic vari-ability over the North Atlantic. - Meteorology at the Millennium. R. Pearce, Ed., Academic Press, London, 143$151,2001$.

4. Gerstengarbe F.-W und Werner P.C., Rüge U. Katalog der großwetterlagen Europas (1881-1998) nach Paul Hess und Helmuth Brezowsky, Potsdam, Offenbach a. M. 1999

5. Rasmusson, E., Wallace, J. Meteorological aspects of the el nino /southern oscillation // Science 16 Dec 1983: Vol. 222, Issue 4629, pp. 1195-1202.

DOI: $10.1126 /$ science.222.4629.119 